\title{
Comparison of Hepatic-like Cell Production from Human Embryonic Stem Cells and Adult Liver Progenitor Cells: CAR Transduction Activates a Battery of Detoxification Genes
}

\author{
Natalie Funakoshi • Cédric Duret • \\ Jean-Marc Pascussi • Pierre Blanc • Patrick Maurel • \\ Martine Daujat-Chavanieu • Sabine Gerbal-Chaloin \\ Published online: 6 January 2011 \\ (C) The Author(s) 2011. This article is published with open access at Springerlink.com
}

\begin{abstract}
In vitro production of human hepatocytes is of primary importance in basic research, pharmacotoxicology and biotherapy of liver diseases. We have developed a protocol of differentiation of human embryonic stem cells (ES) towards hepatocyte-like cells (ES-Hep). Using a set of human adult markers including CAAT/enhancer binding protein (C/EBPalpha), hepatocyte nuclear factor 4/7 ratio (HNF4alpha1/ HNF4alpha7), cytochrome P450 7A1 (CYP7A1), CYP3A4 and constitutive androstane receptor (CAR), and fetal markers including alpha-fetoprotein, CYP3A7 and glutathione Stransferase $\mathrm{P} 1$, we analyzed the expression of a panel of 41
\end{abstract}

Electronic supplementary material The online version of this article (doi:10.1007/s12015-010-9225-3) contains supplementary material, which is available to authorized users.

N. Funakoshi $\cdot$ C. Duret $\cdot$ J.-M. Pascussi $\cdot$ P. Blanc $\cdot$ P. Maurel $\cdot$ M. Daujat-Chavanieu $\cdot$ S. Gerbal-Chaloin INSERM,

U632, Montpellier, France

N. Funakoshi $\cdot$ C. Duret $\cdot$ J.-M. Pascussi $\cdot$ P. Blanc $\cdot$ P. Maurel $\cdot$

M. Daujat-Chavanieu $\cdot$ S. Gerbal-Chaloin $(\bowtie)$

Institute of Research in Biotherapy,

CHU Montpellier, Hopital Saint Eloi,

80 Av Augustin Fliche,

34295, Montpellier cedex 5, France

e-mail: sabine.gerbal-chaloin@inserm.fr

N. Funakoshi $\cdot$ C. Duret $\cdot$ J.-M. Pascussi $\cdot$ P. Blanc $\cdot$ P. Maurel

M. Daujat-Chavanieu $\cdot$ S. Gerbal-Chaloin

Université MONTPELLIER1, UFR Médecine,

Montpellier, France

N. Funakoshi $\cdot$ P. Blanc

Service d'Hepato-Gastroenterologie B,

CHU Montpellier, Hopital Saint Eloi,

80 Av Augustin Fliche,

34295, Montpellier cedex 5, France genes in ES-Hep comparatively with human adult primary hepatocytes, adult and fetal liver. The data revealed that after 21 days of differentiation, ES-Hep are representative of fetal hepatocytes at less than 20 weeks of gestation. The glucocorticoid receptor pathway was functional in ES-Hep. Extending protocols of differentiation to 4 weeks did not improve cell maturation. When compared with hepatocyte-like cells derived from adult liver non parenchymal epithelial (NPE) cells (NPEHep), ES-Hep expressed several adult and fetal liver makers at much greater levels (at least one order of magnitude), consistent with greater expression of liver-enriched transcription factors Forkhead box A2, C/EBPalpha, HNF4alpha and HNF6. It therefore seems that ES-Hep reach a better level of differentiation than NPE-Hep and that these cells use different lineage pathways towards the hepatic phenotype. Finally we showed that lentivirus-mediated expression of xenoreceptor CAR in ES-Hep induced the expression of several detoxification genes including CYP2B6, CYP2C9, CYP3A4, UDPglycosyltransferase $1 \mathrm{~A} 1$, solute carriers $21 \mathrm{~A} 6$, as well as biotransformation of midazolam, a CYP3A4-specific substrate.

Keywords Human embryonic stem cells · Adult hepatic progenitors $\cdot$ Hepatic differentiation $\cdot$ Hepatocyte .

Maturation $\cdot$ Lentivirus vector $\cdot$ Detoxification

\begin{tabular}{|c|c|}
\hline \multicolumn{2}{|c|}{ Abbreviations } \\
\hline hES & Human embryonic stem cell \\
\hline ES-Hep & $\begin{array}{l}\text { Embryonic stem cell-derived hepatocyte-like } \\
\text { cells }\end{array}$ \\
\hline NPE-Hep & $\begin{array}{l}\text { non parenchymal epithelial cell-derived } \\
\text { hepatocyte-like cells }\end{array}$ \\
\hline $\mathrm{PCHH}$ & primary cultures of human hepatocytes \\
\hline TO & tryptophan 2,3-dioxygenase \\
\hline TAT & tyrosine aminotransferase \\
\hline
\end{tabular}




$\begin{array}{ll}\text { GS } & \text { glutamine synthetase } \\ \text { G6P } & \text { glucose-6-phosphatase } \\ \text { PEPCK } & \text { phosphoenolpyruvate carboxykinase } \\ \text { SLC2A2 } & \text { Glut2 } \\ \text { CPS1 } & \begin{array}{l}\text { carbamoyl phosphate synthase } \\ \text { pyruvate kinase of liver }\end{array} \\ \text { PKL } & \begin{array}{l}\text { cholesterol } 7 \alpha \text {-hydroxylase } \\ \text { CYP7A1 }\end{array} \\ \text { ALB } & \text { albumin } \\ \text { AAT } & \text { alpha-1 antitrypsin } \\ \text { AFP } & \text { alpha fetoprotein } \\ \text { TTR } & \text { transthyretin } \\ \text { FIB } & \text { Fibrinogen } \\ \text { ApoH } & \text { Apolipoprotein H } \\ \text { FII } & \text { blood coagulation factor II } \\ \text { FV } & \text { blood coagulation factor V } \\ \text { CYP } & \text { Cytochrome P450 } \\ \text { POR } & \text { Cytochrome P450 reductase } \\ \text { UGT } & \text { UDP-glycosyltransferase } \\ \text { GST } & \text { Glutathione S-transferase } \\ \text { PXR, } & \text { pregnane X receptor } \\ \text { NR1I2 } & \\ \text { CAR, } & \text { constitutive androstane receptor } \\ \text { NR1I3 } & \\ \text { AhR } & \text { aryl hydrocarbon receptor } \\ \text { GR, } & \text { glucocorticoid receptor } \\ \text { NR3C1 } & \text { Multiple Reaction Monitoring } \\ \text { MRM } & \text { a }\end{array}$

\section{Introduction}

Orthotopic liver transplantation is currently the only means to efficiently cure liver failure regardless of origin (drugs, alcohol or viral infection). However, liver donor scarcity strongly limits this approach. New strategies to produce human hepatocytes are therefore needed. These are based on the proliferative capacity of human embryonic stem (hES) cells and adequate protocols of in vitro differentiation towards mature hepatocytes. Moreover, due to the wide range of functions performed by the liver, hepatocytes derived from hES cells (ES-Hep) can be a useful tool for basic research and pharmacotoxicology.

One of the earliest commitment steps in embryogenesis is the formation of the primary germ layers ectoderm, mesoderm and endoderm, the founder populations of all somatic cell types in the body [1]. The liver develops from definitive endoderm (DE) that is generated from the anterior primitive streak (PS). Along the PS an inverted gradient of TGF $\beta /$ Nodal/Activin and $\mathrm{Wnt} / \beta$ catenin constitutes a signaling environment that is responsible for the induction of the hepatic lineage [2]. The cardiac mesoderm and septum transversum mesenchyme induce hepatic specification of the adjacent endodermal epithelium through bone morphogenetic protein (BMP2-4) [3] and fibroblast growth factor (FGF1-2-8) signaling [4, 5]. At this stage, endothelial cells seem to have an organogenic role and provide a crucial growth stimulus for hepatic bud formation [6]: the cells are thereafter referred to as hepatoblasts. Although these cells already express some genes specific to fully differentiated hepatocytes, such as serum albumin, in the fetal liver hepatoblasts give rise to hepatocytes and bile duct cells (cholangiocytes). The hepatic versus bile duct phenotype specification process is not yet fully understood; nevertheless Notch [7] and TGF- $\beta$ /activin pathways [8] seem to play crucial roles in this cell-fate decision.

During mid and late fetal life, the liver is the major hematopoietic organ. The secretion by hematopoietic cells of oncostatin M (OSM) coordinates the late stages of embryonic liver development and promotes the maturation of fetal hepatoblasts into hepatocytes [9]. This final maturation step also involves HGF (Hepatocyte Growth Factor), soluble compounds (glucocorticoid, insulin...), extracellular matrix components and cell-cell interaction and cooperation [10]. At birth, the function of the liver shifts from hematopoiesis to homeostasis and detoxification. Numerous adult functions are acquired and fetal ones are lost.

If liver development is well described in rodents, information is scarce concerning human development. Important differences exist between these species, as documented for many genes [11-18]. In addition, liver lobule architecture is established at birth in rodents, whereas it appears to be already specified at week 20-22 of gestation in humans, which may have a strong impact on the pattern of metabolic activities $[19,20]$. It is therefore necessary to take these differences into account when considering hES differentiation towards hepatocytes. Recent studies from this [21] and other laboratories [22] have allowed to identify genes that are true markers of human liver maturation.

In the last five years, numerous papers have reported the generation of hepatocytes from human embryonic stem cells [23-29]. In most cases, these studies used HepG2 as a reference hepatic cell, or used the time-dependent increase of hepatic markers as a means to follow differentiation. The aim of this work was to investigate the differentiation of hES towards hepatocytes using several reference cell/tissue types including fetal and adult liver tissues, adult primary human hepatocytes and adult liver progenitors [30, 31].

\section{Materials and Methods}

\section{Chemicals}

Growth factors (Activin A, FGF, HGF, BMP, OSM) were obtained from Peprotech (Neuilly sur Seine, France). Mouse Wnt3a was from Chemicon (Hants, England). 
Culture medium and supplements are from Invitrogen (Cergy Pontoise, France). Collagen I coated plates and Matrigel are from Becton-Dickinson (Le Pont de Claix, France). LY294002, DMSO, clotrimazole and midazolam are from Sigma.

\section{Cell Culture and Differentiation}

Human embryonic stem cells HUES-1 (obtained from Dr Douglas Melton, Harvard University) were cultured and amplified onto mouse embryonic fibroblasts (MEF), using DMEM medium supplemented with $10 \%$ KO-SR and $10 \mathrm{ng} / \mathrm{ml} \mathrm{FGF2}$. For differentiation, a single cell suspension of hES was transferred to a Matrigel ${ }^{\mathrm{TM}}$ coated plate $\left(40 \mu \mathrm{g} / \mathrm{cm}^{2}\right)$ and maintained in MEF conditioned medium $(\mathrm{CM})$ for 24-48 $\mathrm{h}$. When cells reached $50 \%$ confluence, medium was replaced by an endoderm priming medium for 5 days consisting of DMEM $5.5 \mathrm{mM}$ glucose, $2 \mathrm{mM}$ glutamine, $0.1 \mathrm{mM}$ non essential amino-acid, 10\% KO-SR supplemented with Activin A (100 ng/ml), FGF2 (10 ng/ml), Wnt3a (25 ng/ml) and LY294002 $(30 \mu \mathrm{M})$. The medium was changed daily. For hepatic induction, KO-SR was reduced to $2 \%$ and supplemented with BMP4 (50 ng/ml), FGF4 (25 ng/ml) and $1 \%$ DMSO (Fig. 1a). For the differentiation process, cells were transferred to collagen I coated dishes in a medium consisting of $60 \%$ low glucose DMEM, $40 \%$ MCDB-201, supplemented with insulin-transferrinselenium (ITS+1), $5 \mu \mathrm{M}$ dexamethasone, $0.1 \mathrm{mM}$ ascorbic acid 2-phosphate, $20 \mathrm{ng} / \mathrm{ml} \mathrm{HGF,} 25 \mathrm{ng} / \mathrm{ml}$ FGF4, $10 \mathrm{ng} / \mathrm{ml}$ Oncostatin M (OSM). After $24 \mathrm{~h}$, cold medium supplemented with $0.3 \mathrm{mg} / \mathrm{ml}$ Matrigel TM was added to the cells. Medium (without Matrigel addition) was then changed twice a week.

\section{Other Liver Cells}

HepG2-C3 hepatocellular carcinoma cell line was obtained from ATCC and cultured as recommended. Non parenchymal epithelial cells (NPE) were isolated, cultured and differentiated as described previously [31]. Human Fetal Liver (FL) samples (20 and 23 weeks) were obtained from CliniSciences (Montrouge, France). A mix of five human Adult Liver (AL) mRNA samples isolated from five lobectomies, and a mix of six mRNA samples isolated from Primary Cultures of Human Hepatocytes (PCHH) cultured for 3-4 days in ISOM medium [32] were used as references.

\section{RNA Isolation and RT-PCR}

After extraction with Trizol reagent (Invitrogen), $1 \mu \mathrm{g}$ of total RNA was reverse-transcribed using random hexaprimer and the MMLV reverse transcriptase kit (Invitrogen).
Quantitative PCR was performed using Roche SYBER Green reagent and LightCycler 480 apparatus (Roche Diagnostic, Meylan, France). Amplification specificity was evaluated by determining the product melting curve. The expression of RPLP0 mRNA was used for relative quantification. Results are expressed as relative mRNA levels or as the percentage of mRNA expression in PCHH as indicated in figure legends. Sequences of primers are summarized in Table S1. The following program was used : one step at $95^{\circ} \mathrm{C}$ for $10 \mathrm{~min}, 50$ cycles of denaturation at $95^{\circ} \mathrm{C}$ for $10 \mathrm{~s}$, annealing at $65^{\circ} \mathrm{C}$ for $15 \mathrm{~s}$, elongation at $72^{\circ}$ $\mathrm{C}$ for 15 . miR-122 was quantified by RT-PCR as described [33].

\section{Western Blotting}

The secretion of proteins in 4 day-aliquots of culture media was assayed by western blotting. Primary antibodies directed against human albumin, alpha-1 antitrypsin (AAT) (Dako Cytomation, Trappes, France) factor II (FII), factor V (FV) (USBiological), alpha-fetoprotein (AFP) (Thermo Fisher Scientific, Runcorn, UK) or fibrinogen (Sigma) were used at 1/1000 dilution. Anti-mouse, -goat or -rabbit horseradish peroxidase-conjugated secondary antibodies were used at $1 / 10000$, and chemiluminescent signal detection was performed with the ECL Western Blotting Detection kit (Amersham, England).

\section{ELISA}

Albumin and AAT proteins were quantified in 4 dayaliquots of culture media using AssayPro ELISA Kits (St Charles, MO) as recommended.

\section{Urea Assay}

The urea production in 4 day-aliquots of culture media was assayed by a colorimetric assay (Gentaur, Brussel, Belgium) as previously described [30].

\section{Indirect Immunofluorescence}

Fixed cells were permeabilized with $0.2 \%$ Triton X-100 in TBS for $5 \mathrm{~min}$. Mouse antibodies directed against N-CAM (NeoMarkers) and cytokeratin 8/18 (NovoCastra), rabbit antibodies directed against HNF4 (Santa-Cruz) and AFP (Thermo Fisher Scientific), goat antibody directed against FOXA2 (R\&D) and goat antibody-FITC directed against human albumin (Bethyl Laboratory) in PBS 3\% FCS were applied to the cells for $1 \mathrm{~h}$ at room temperature. After washing, cells were incubated with anti-mouse Alexa-488, anti-rabbit or anti-goat Alexa-568 secondary antibodies (1/ 1000 dilution, Invitrogen) for $45 \mathrm{~min}$ at room temperature. 
Fig. 1 Differentiation of hES cells. A) Protocol. Arrows indicate medium renewal. B) Photomicrographs of morphological changes during differentiation. C) and D) immunofluorescence analysis of N-CAM, FOXA2, AFP, HNF4, CK8-18 and Albumin in ES-Hep and PCHH. Only overlays (FOXA2-green/AFPred; ALB-green/CK8-18 or HNF4-red) are shown here. See Supplementary Fig. 2 for further detail

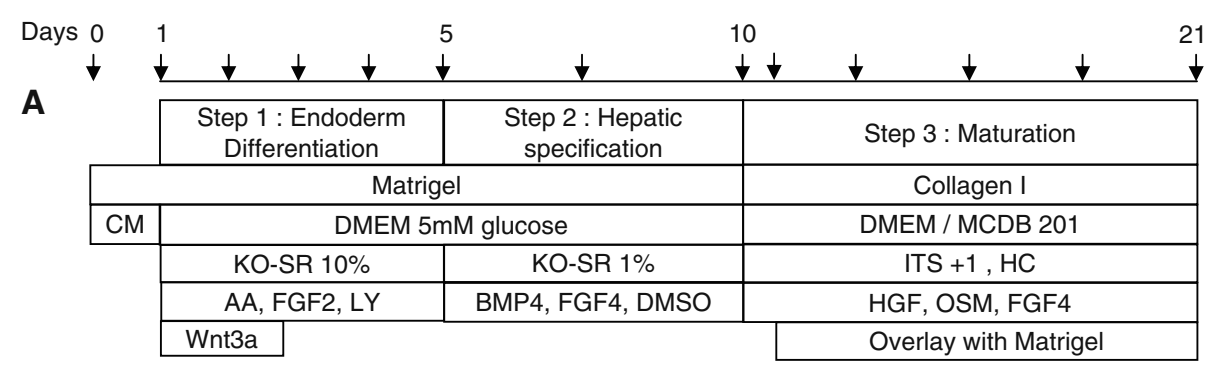

B

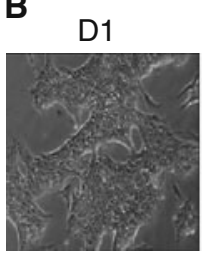

D5

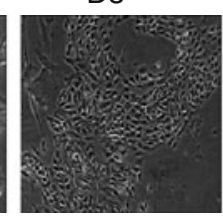

D10

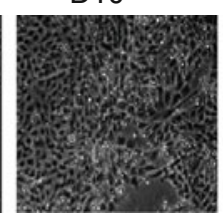

D15

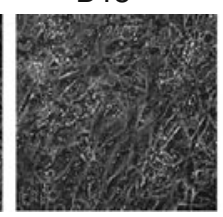

D21
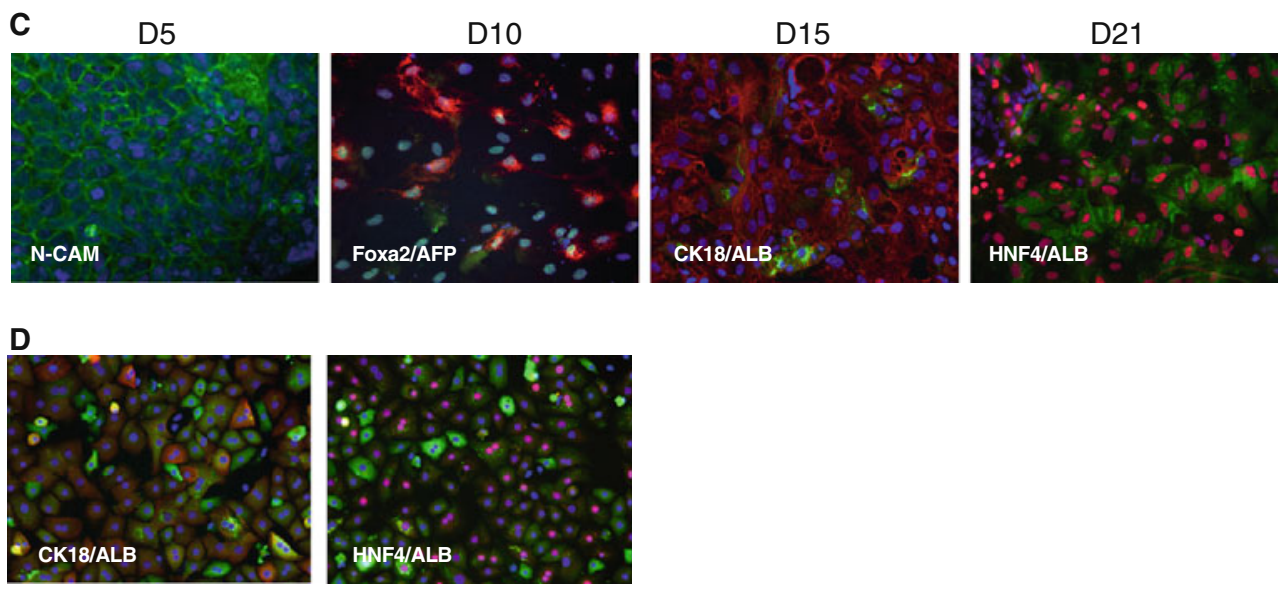

Nuclei were labeled with Hoechst 33258. Immunofluorescent labeling was examined under a fluorescent microscope (Leica Microsystem, Rueil-Malmaison, France) and images were analyzed using Metamorph software (Universal Imaging Corporation, Downington, PA).

\section{LDL Uptake}

After 21 days of differentiation Hep-ES were incubated with $20 \mu \mathrm{g} / \mathrm{ml}$ of Dil-LDL (1,1'-dioctadecyl-3,3,3',3'tetramethyl-indocarbocyanine perchlorate, Molecular Probes, Eugene, OR) for $4 \mathrm{~h}$ in culture medium. Cells were washed with PBS and fixed in $3.2 \%$ formaldehyde. For nucleus staining, cells were incubated for $1 \mathrm{~h}$ with $3 \mu \mathrm{M}$ Hoechst 33258 without permeabilization. Cells were examined as indicated above.

\section{Glycogen Uptake}

After 21 days of differentiation, the storage of glycogen in Hep-ES was evaluated using the Periodic Acid Schiff Assay staining as recommended by the manufacturer (Sigma).
Lentivirus

FG12-CMV and the FG12-hCAR were obtained after amplification of the CMV or the CMV-hCAR cassettes (pcDNA3CMV Hpa-1 F: acGTTAAC CGTTGACATTGATTATTGAC; pcDNA3-Hpa-1 Rev: acGTTAACTgatcagcgggtttaaactc) from the pcDNA3 or the pcDNA3-hCAR (gifts from Masahiko Negishi, NIEHS, NC USA) plasmids and insertion into Hpa-1 linearized FG12 [34]. Lentivirus production and cell transduction were performed as previously described [35, 36]. HepG2-C3 and ES-Hep were transduced at D15 or D20, respectively, with 10 and 10,20 and $50 \mu \mathrm{l}$ of lentivirus solution and analyzed 3, 7 and 10 days later, after treatment with or without clotrimazole for the last $24 \mathrm{~h}$.

\section{Metabolic Activity}

After 21 days of differentiation hES-Hep cells were incubated with $5 \mu \mathrm{M}$ midazolam. At $24 \mathrm{~h}, 400 \mu \mathrm{L}$ of acetonitrile/water $(30 / 10, v / v)$ were added to each well and extracellular medium and cell homogenate were mixed and submitted to analysis for substrate and metabolites by LC/MS-MS, using MassLynx 4.0 Software (Waters-Micromass, Milford MA). 


\section{Results}

In vitro Production of Definitive Endoderm (DE): Effect of Glucose and Wnt3a

The differentiation protocol used for HuES-1 cells is illustrated in Fig. 1a. This protocol is based on previous papers that emphasized the role of stimulatory factors such as Activin, LY294002, Wnt3a, DMSO, KO-SR [29, 3741]. mRNA expression of mesendodermal and endodermal markers was analyzed from D1 to D5 (Fig. 2a). As expected, Brachyury (mesendodermal marker) mRNA reached a maximum at D2 and decreased thereafter. Note that the maximum level was greater and the decrease sharper in low glucose medium. No significant effect of glucose concentration was observed in the induction kinetics of endodermal marker transcripts Sox17, CXCR4, FOXA2, and HEX. However, while these transcript levels decreased between D4 and D5 in high glucose $(25 \mathrm{mM})$ medium, they were maintained at their maximum up to D5 in low glucose (5.5 mM) medium. Thus, DMEM culture medium containing $5.5 \mathrm{mM}$ glucose was routinely used.

In the next series of experiments, HuES-1 cells were cultured as described above in the absence or presence of Wnt3a (25 ng/ml) for 48 (D1 to D3) or $96 \mathrm{~h}$ (D1 to D5) (Fig. 2b). The mRNA expression of mesendodermal (Brachyury) and primitive streak (MIXL1) markers increased with the duration of Wnt3a treatment. However, while mRNA levels of DE markers (Sox17, CER, GSC, HEX, FOXA2 and CXCR4) were strongly increased (4.8 to 33-fold) by Wnt3a exposure between D1 and D3, prolonged Wnt3a exposure (D1 to D5) led to a decrease in DE marker levels. In contrast, ZIC1 (ectodermal marker) mRNA level was strongly reduced by Wnt3a, while Sox7 (visceral endoderm marker) mRNA expression was not affected. Thus, transient exposition of cells to Wnt3a from D1 to D3 was routinely used to induce the DE. During this step, the cells became larger with dark cytoplasm and adopted a more mesenchymal aspect (Fig. 1b-D5), as confirmed by N-CAM expression (Fig. 1c-D5).
A

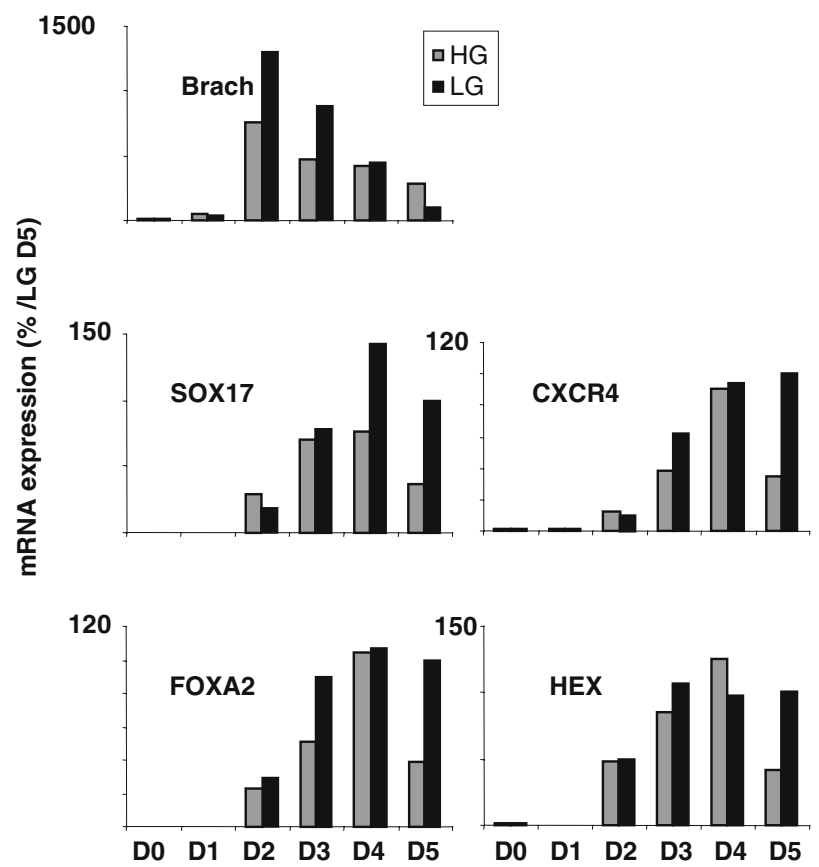

Fig. 2 Optimization of DE specification. a Effect of high (HG) and low (LG) glucose on mRNA expression of development markers (reference level 100 with LG at D5). b Effect of Wnt3a on mRNA
B
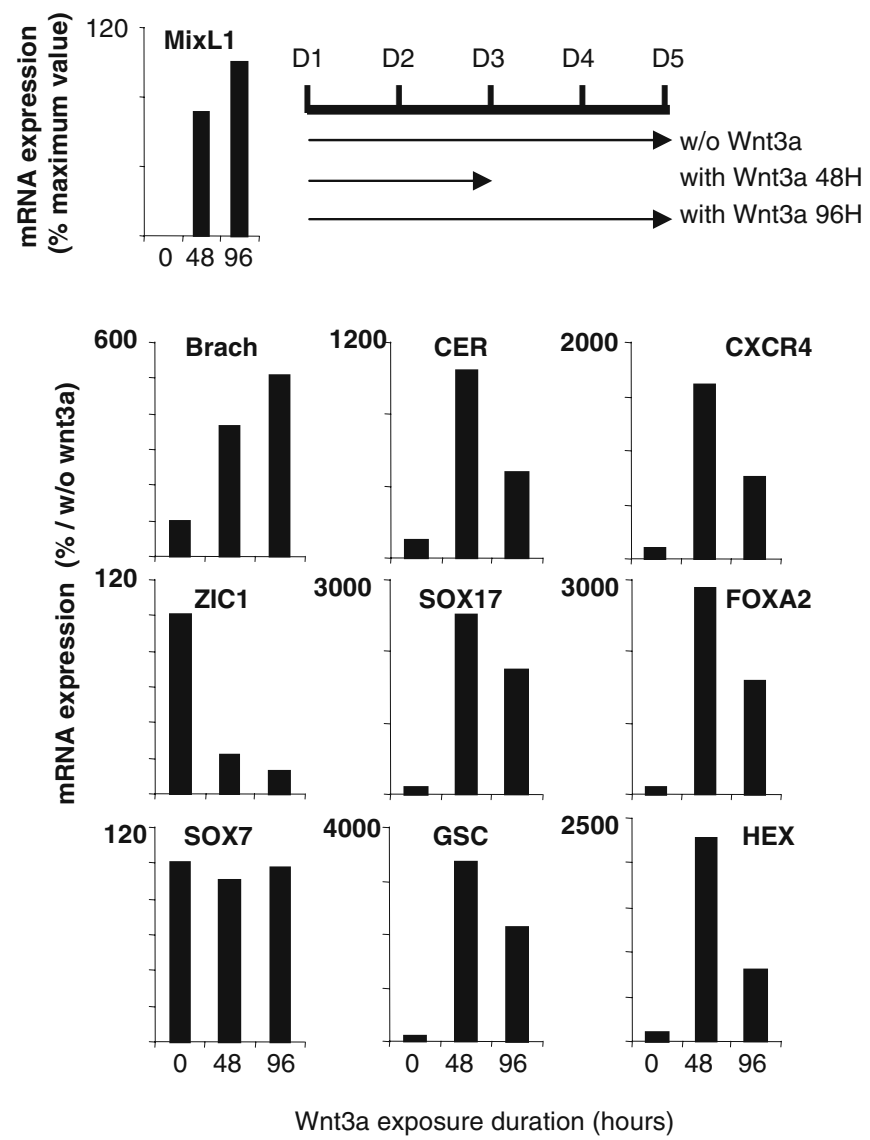

expression of development markers (reference level 100 without Wnt3a at D5) 
Hepatic Specification

Hepatic specification was induced between D5 and D10 (Fig. 1a). In contrast to Jung et al. [42] and in agreement with Cai et al. [25], we observed that different combinations and doses $(25-100 \mathrm{ng} / \mathrm{ml})$ of BMPs and FGFs produced similar effects on the rate of this step (Supplementary Fig. 1A). Thus, for further experiments, we associated BMP4 and FGF4 at 50 and $25 \mathrm{ng} / \mathrm{ml}$, respectively. We further observed that using 1\% DMSO, previously reported as an epigenetic modulator [43], and decreasing KO-SR concentration to $2 \%$ increased the expression level of albumin, AFP, AAT, HNF $4 \alpha 7, \mathrm{HNF} 4 \alpha 1$ and FOXA2 mRNAs (Supplementary Fig. 1B-C). At D10, most of the cells expressed FOXA2/HNF3 $\beta$ and AFP as shown in Fig. 1c and supplementary Fig. 2A.

\section{Hepatic Maturation}

Cell substratum has a strong impact on stem cell differentiation towards hepatocytes [44]. At D10, cells were trypsinized and replated on type-I collagen-coated plates, in a medium containing HGF, FGF4, insulin and glucocorticoids as used by others for MAPC differentiation towards hepatocytes [45]. This medium was complemented with OSM [46]. As first shown in mouse fetal hepatocytes [46] and parenchymal epithelial cells (NPE) [31], matrigel overlay had a stimulating effect on the maturation step. We therefore routinely used this additive at $0.3 \mathrm{mg} / \mathrm{ml}$ in this protocol at D11. Morphological changes during maturation are shown in Fig. 1b. Between D15 and D21, clusters of cells displayed a typical aspect of primary binucleated hepatocytes. Immunofluorescence analysis revealed timedependent increased expression of ALB which colocalizes with CK8/18 (D15) and HNF4 (D21) (Fig. 1c and supplementary Fig. 2A). A similar pattern is observed in PCHH as shown in Fig. 1d and supplementary Fig. 2b. At D21, it can be seen that a significant proportion of cells do not express ALB and/or HNF4. We therefore evaluated the percentage of cells expressing ALB by immunofluorescence and FACS analysis. As shown in supplementary Fig. 3, this cell population represents $40 \%$ of the total number of cells in culture.

\section{Differentiation of hES Cells to Hepatocyte-like Cells}

In order to characterize the phenotype of hES-derived hepatocyte-like cells (ES-Hep), several markers were compared with those evaluated in NPE-derived hepatocyte-like cells (NPE-Hep) [30, 31], primary cultures of adult human hepatocytes ( $\mathrm{PCHH}, n=6$ ), adult liver tissue (AL, $n=5$ ), and fetal liver tissue (FL, mix of samples at 20 23 weeks gestational age). Hepatocellular carcinoma
HepG2-C3, considered as the most differentiated HepG2 clone was analyzed in parallel (Table 1). Note that, expression of markers was weighted by the percentage of cells expressing ALB at D21 (see column hES D21*).

\section{Expression of Liver Enriched Transcription Factors}

Hepatocyte-lineage genes are primarily regulated at the transcriptional level [47]. Analyzing transcription factor expression levels is therefore mandatory. $\mathrm{C} / \mathrm{EBP} \alpha$ and a HNF $4 \alpha 1 / \mathrm{HNF} 4 \alpha 7$ ratio $>1$ [48] are generally considered as adult hepatocyte markers. FOXA2, HNF $4 \alpha 1, \mathrm{HNF} 4 \alpha 7$ and $\mathrm{C} / \mathrm{EBP} \alpha$ mRNA levels sharply reached maximum levels at D10 or D15 and decreased 2- to 5-fold at D21, except for HNF $4 \alpha 7$ (Table 1A). In contrast, HNF1, HNF6, C/EBP $\beta$ and XBP-1 mRNA expression increased slowly, reaching maximum levels at D21, close to levels in PCHH. At D21, the $\mathrm{HNF} 4 \alpha 1 / \mathrm{HNF} 4 \alpha 7$ ratio was clearly $<1$ as in fetal liver.

\section{Secreted Plasma Proteins}

ALB, AAT, TTR, ApoH, FV and FII mRNAs were expressed at very low or non existent levels before D15 (Table 1B), and sharply increased at D15 or D21. AFP, a well known fetal marker, exhibited a tremendous increase between D10 and D15 to reach a level approximately ten times greater than that found in fetal liver. At D21, the expression of ALB, AAT and TTR was greater than in $\mathrm{PCHH}$, while expression of ApoH, FII and FV was lower than that observed in $\mathrm{PCHH}$. The expression of all transcripts was greater than that observed in HepG2-C3 cells, except for ApoH and FV. While AFP protein was not expressed in PCHH (Fig. 3a), expression levels of ALB, AAT, and FV proteins were similar to those observed in $\mathrm{PCHH}$, consistent with transcript levels. Fibrinogen (FIB) was highly expressed in ES-Hep in comparison to $\mathrm{PCHH}$, while the opposite was observed for FII (Fig. 3a). The findings concerning ALB and AAT were confirmed by ELISA (Fig. 3b).

\section{Metabolism}

Hepatocytes play crucial roles in amino acid metabolism (TO, TAT, GS), insulin-regulated glucose homoeostasis [49] (G6P, PEPCK, SLC2A2), urea (CPS1), bile acid synthesis (CYP7A1) [50], and lipid homeostasis [51]. Apart from GS, none of these transcripts was significantly expressed at D1 and all exhibited a major increase between D15 and D21 (Table 1C), consistent with transcription factor expression before or at D15 (Table 1A). Indeed, G6P and PEPCK are HNF4- and C/EBP $\alpha$-target genes, and Glut2 is a FOXA2- and HNF6-target gene [47]. At D21, TO, PEPCK, Glut2, CPS1 and PKL reached levels admittedly lower but close to those measured in PCHH. 
Table 1 Quantitative RT-PCR analysis of mRNA expression of hepatic markers during hES differentiation (from D1 to D21) in comparison with NPE differentiation (D1 to D18), FL, AL and
HepG2-C3. mRNA levels quoted in this table have been normalized with respect to corresponding levels in $\mathrm{PCHH}$ arbitrarily taken as 100

\begin{tabular}{|c|c|c|c|c|c|c|c|c|c|c|c|c|c|}
\hline & $\begin{array}{c}\mathrm{hES} \\
\mathrm{D} 1\end{array}$ & $\begin{array}{c}\mathrm{hES} \\
\mathrm{D} 5\end{array}$ & $\begin{array}{l}\mathrm{hES} \\
\mathrm{D} 10\end{array}$ & $\begin{array}{l}\text { hES } \\
\text { D15 }\end{array}$ & $\begin{array}{l}\mathrm{hES} \\
\mathrm{D} 21\end{array}$ & $\begin{array}{c}\mathrm{hES} \\
\mathrm{D} 21^{*}\end{array}$ & $\begin{array}{c}\text { NPE } \\
\text { D1 }\end{array}$ & $\begin{array}{l}\text { NPE } \\
\text { D7 }\end{array}$ & $\begin{array}{l}\text { NPE } \\
\text { D18 }\end{array}$ & FL & $\begin{array}{c}\text { HepG2- } \\
\text { C3 }\end{array}$ & $\mathrm{AL}$ & $\mathrm{PCHH}$ \\
\hline \multicolumn{14}{|c|}{ A - Transcription Factors } \\
\hline FOXA2 & 0.7 & 56 & 256 & 54 & 56 & 140 & 15 & 16 & 13 & 264 & 73 & 203 & 100 \\
\hline $\mathrm{C} / \mathrm{EBP} \alpha$ & 0.03 & 0.08 & 0.2 & 13.5 & 5 & 12.5 & 0 & 0 & 0.2 & 0.3 & 0.2 & 1400 & 100 \\
\hline $\mathrm{C} / \mathrm{EBP} \beta$ & 2 & 2 & 3.5 & 10.5 & 22.5 & 56.2 & 51 & 62.5 & 61.5 & 189 & 116 & 219 & 100 \\
\hline $\mathrm{HNF} 4 \alpha 1$ & 0.009 & 0.01 & 128 & 73 & 62 & 155 & 0.4 & 11 & 21 & 85 & 72 & 188 & 100 \\
\hline HNF4 47 & 0.7 & 1.8 & 123 & 75 & 159 & 397 & 1.2 & 33 & 17 & 135 & 85 & 53 & 100 \\
\hline Ratio $\alpha 1 / \alpha 7$ & 0.01 & 0.005 & 1 & 1 & 0.4 & 0.4 & 0.3 & 0.3 & 1.2 & 0.6 & 0.8 & 3.5 & 1 \\
\hline HNF1 $\alpha$ & 0 & 0 & 4 & 21 & 35 & 87.5 & 0.4 & 15 & 11 & 252 & 72 & 132 & 100 \\
\hline HNF6 & 2.7 & 0.7 & 2.8 & 97 & 339 & 847.5 & 0.08 & 0.07 & 0.2 & 758 & 91 & 299 & 100 \\
\hline XPB1 & 12 & 5.2 & 20.6 & 51 & 80 & 200 & 24 & 50 & 69 & 306 & 126 & 354 & 100 \\
\hline \multicolumn{14}{|c|}{ B - Secreted plasma proteins } \\
\hline $\mathrm{AAT}$ & 0 & 0.1 & 1.3 & 138 & 472 & 1180 & 4.5 & 45 & 160 & 572 & 64 & 284 & 100 \\
\hline ALB & 0 & 0.1 & 0.3 & 0.6 & 201 & 502.5 & 0.6 & 6.6 & 290 & 502 & 24 & 264 & 100 \\
\hline AFP & 0 & 5 & 1443 & $1.10^{7}$ & $2.10^{7}$ & $5.10^{7}$ & 0 & 80 & 432 & $2.10^{6}$ & $7.10^{5}$ & 1056 & 100 \\
\hline TTR & 0 & 0 & 35 & 1021 & 441 & 1102 & nd & nd & 1.2 & 160 & 18.7 & 619 & 100 \\
\hline $\mathrm{ApoH}$ & 0 & 0 & 0 & 1.2 & 21.2 & 53 & 0 & 0.5 & 26 & 337 & 78 & 1315 & 100 \\
\hline FII & 0 & 0 & 1.3 & 10.8 & 35.1 & 87.7 & nd & nd & 0.3 & 261 & 0.5 & 230 & 100 \\
\hline $\mathrm{FV}$ & 0 & 0 & 0.075 & 14.4 & 75 & 187.5 & 0.5 & 7.1 & 21.2 & 504 & 111.3 & 430 & 100 \\
\hline \multicolumn{14}{|c|}{ C - Metabolism } \\
\hline $\mathrm{TO}$ & 0.7 & 0.01 & 0.05 & 10.2 & 10.2 & 25.5 & 0.1 & 8.8 & 13.3 & 65 & 0.03 & 2840 & 100 \\
\hline TAT & 0 & 0 & 0 & 0.05 & 0.5 & 1.25 & 0.01 & 0.1 & 0.8 & 21 & 1.3 & 201 & 100 \\
\hline G6P & 0 & 0 & 0 & 32 & 1150 & 2875 & 0.02 & 3.3 & 300 & 1072 & 18 & 4843 & 100 \\
\hline PEPCK & 0.03 & 0.05 & 0.2 & 9.9 & 24.8 & 62 & 0.2 & 0.3 & 8.7 & 4431 & 11 & 9218 & 100 \\
\hline Glut2 & 0 & 0 & 0 & 3 & 63.3 & 158 & 2 & 5 & 7.9 & 1162 & 57.3 & 956 & 100 \\
\hline CYP7A1 & 0 & 0 & 0 & 0.12 & 14.7 & 36.75 & 0 & 0 & 0 & 0.06 & 0.6 & 1494 & 100 \\
\hline GS & 34 & 41 & 220 & 76 & 183 & 457.5 & 119 & 214 & 327 & 651 & 193 & 398 & 100 \\
\hline CPS1 & 0.4 & 0.1 & 0.3 & 17.2 & 55.4 & 138.5 & 0.2 & 0.4 & 2.4 & 100 & 1.21 & 264 & 100 \\
\hline PKL & 0.4 & 0.04 & 0.2 & 1.2 & 14 & 35 & 0.03 & 0.08 & 0.4 & 514 & 5.5 & 509 & 100 \\
\hline \multicolumn{14}{|c|}{ D - Detoxification } \\
\hline CYP1A1 & 8 & 0.09 & 27 & 713 & 1865 & 4662 & nd & nd & 149 & 3.9 & 73 & 3902 & 100 \\
\hline CYP1A2 & 0.07 & 0 & 0.02 & 0.08 & 0.2 & 0.5 & 0 & 0 & 0.22 & 0 & 0.02 & 4275 & 100 \\
\hline CYP2B6 & 27.7 & 0.79 & 0 & 0.03 & 0.4 & 1 & 0 & 0.25 & 2.5 & 0.1 & 2.3 & 7436 & 100 \\
\hline CYP3A4 & 0 & 0 & 0.003 & 0.6 & 0.9 & 2.25 & 0.2 & 0.2 & 0.9 & 0.2 & 0.01 & 5429 & 100 \\
\hline CYP3A7 & 0 & 0 & 0 & 84 & $1.10^{5}$ & $2.510^{5}$ & 0 & 0 & 3.3 & 53630 & 5.4 & 264 & 100 \\
\hline POR & 7 & 5.6 & 10.7 & 20.7 & 38.2 & 95.5 & 12.1 & 16.6 & 20.4 & 195 & 136 & 461 & 100 \\
\hline SLC21A6 & 0 & 0 & 0.003 & 0.2 & 0.3 & 0.75 & 0.05 & 0.7 & 0.3 & 491 & 0.005 & 1340 & 100 \\
\hline UGT1A1 & 0.03 & 0.01 & 0.01 & 0.2 & 1.6 & 4 & 25 & 1.5 & 0.6 & 0.08 & 0.08 & 234 & 100 \\
\hline GSTA3 & 0 & 0 & 31 & 2522 & 2470 & 6175 & 0 & 0 & 10.2 & 34 & 2.8 & 2919 & 100 \\
\hline GSTP1 & 4795 & 4189 & 4873 & 3722 & 2304 & 5760 & 1909 & 2603 & 2247 & 1643 & 3.1 & 383 & 100 \\
\hline \multicolumn{14}{|c|}{ E - Nuclear Receptors and Coactivators } \\
\hline AhR & 3 & 7.5 & 20 & 25 & 76 & 190 & 307 & 271 & 211 & 231 & 642 & 276 & 100 \\
\hline PXR & 1 & 0.2 & 0.5 & 1.2 & 3 & 7.5 & 0.07 & 0.09 & 0.4 & 11 & 18 & 2900 & 100 \\
\hline CAR & 0 & 0 & 0.3 & 27 & 9.5 & 23.7 & 0 & 0 & 0.5 & 0.3 & 0 & 1400 & 100 \\
\hline GR & 9.7 & 7.7 & 16 & 63 & 124 & 310 & 136 & 202 & 190 & 524 & 289 & 217 & 100 \\
\hline SRC1 & 26 & 42 & 118 & 163 & 246 & 615 & 126.5 & 194.3 & 189.7 & 491 & 161 & 254 & 100 \\
\hline PGC1 $\alpha$ & 10.4 & 9.8 & 25.5 & 30 & 136 & 340 & 94 & 265 & 218 & 856 & 581 & 1383 & 100 \\
\hline \multicolumn{14}{|c|}{ F - miRNA } \\
\hline $\begin{array}{c}\text { miRNA- } \\
122\end{array}$ & 0.008 & 0.08 & 0.2 & 1.4 & 17 & 42.5 & nd & nd & nd & 40 & nd & nd & 100 \\
\hline
\end{tabular}

nd : not determined - $0:$ not detected

\begin{tabular}{|l|l|l|l|l|}
\hline $0-25 \%$ & $26-50 \%$ & $51-75 \%$ & $76-100 \%$ & $>100$ \\
\hline
\end{tabular} 
A

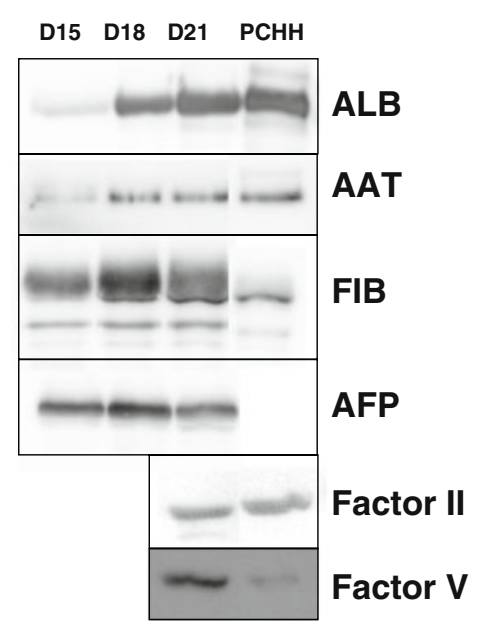

B
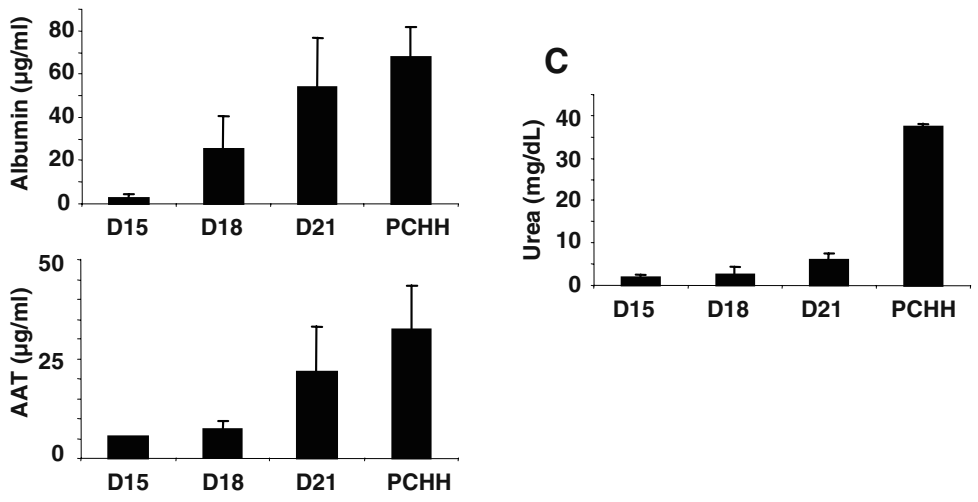

D

E

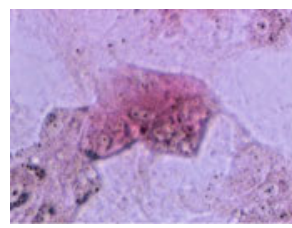

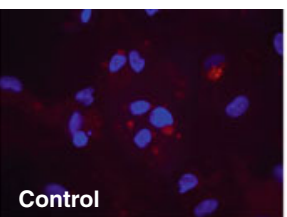

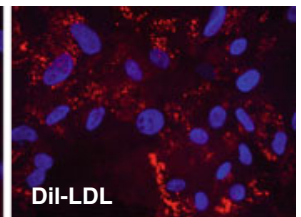

Fig. 3 Expression of plasma proteins in 4 days-aliquots of culture medium of ES-Hep after 15, 18 and 21 days of differentiation measured by Western-blot (a) and ELISA (b). Production of these

TAT remained at a very low level with respect to $\mathrm{PCHH}$ while G6P exhibited level 10 times greater, as in FL. At D21, expression of CYP7A1 reached $15 \%$ of that observed in PCHH. As this gene is not expressed in FL (at week 24) it was considered as another marker of maturation, in agreement with previous observations in piglets [52]. Urea synthesis increased from D15 to D21 to reach $15 \%$ of the activity observed in PCHH (Fig. 3c). Finally, hES-Hep cells were able to store glycogen and uptake LDL as assessed by fluorescence labeling (Fig. 3d and e).

\section{Detoxification}

Xenobiotic biotransformation and excretion is dependent on the presence and distribution of phase I, phase II and transporter genes [53]. Cytochrome P450s (CYPs) are mixed function monooxygenases and are major phase I enzymes. In contrast to adult liver, fetal hepatocytes exhibit a modest detoxification function. CYP gene expression increases during liver ontogeny and is characterized by a strong expression of CYP3A7 in the human fetal liver [54]. In the perinatal period, expression of CYP3A7 decreases and that of CYP3A4 (its adult counterpart) increases [21]. As with CYP3A4, other CYPs including CYP2B6, CYP2C8/9 and CYP1A2 are major CYPs expressed in adult liver. In contrast to CYP1A2, CYP1A1 is also expressed in non hepatic tissues such as trachea and lung [54].

Except for CYP2B6, none of these genes was significantly expressed at D1, and all exhibited a major increase between D15 and D21 (Table 1D). CYP3A4 reached 1\% of the level proteins by $\mathrm{PCHH}$ was analyzed in comparison. $\mathbf{c}$ Urea production. d Glycogen storage. e Dil-LDL uptake

detected in PCHH, while CYP3A7 expression was 100 times higher than in PCHH and close to that observed in FL. At D21, CYP1A1 was expressed at a high level in ES-Hep in contrast to CYP1A2. Surprisingly, CYP2B6 was expressed at a significant level in undifferentiated ES cells (corresponding to $25 \%$ of CYP2B6 mRNA in PCHH) and decreased rapidly thereafter. POR, the specific NADPHdependent reductase involved in CYP enzyme function, was expressed at a significant level in undifferentiated cells (D1).

UGT1A1 is a glucuronidation enzyme exclusively expressed in adult liver [55] (Table 1D). Its mRNA expression increased during ES-Hep differentiation to reach $1.5 \%$ of PCHH mRNA levels. The mRNA expression of SLC21A6, a hepatospecific bilirubin transporter, was also induced during ES-Hep differentiation but only reached a very low level at D21 in comparison to PCHH. In contrast, SLC21A6 mRNA was expressed at a high level in FL as observed by others [56]. It is remarkable that GSTA3 and P1 levels were almost 20 times greater in ES-Hep as compared with PCHH. Moreover, GSTP1 was expressed at an even greater level in undifferentiated DE cells, in sharp contrast with GSTA3. Indeed, GSTP1 and GSTA3 are generally considered as fetal and adult markers, respectively.

\section{Expression of Nuclear Receptor Implicated in Detoxification Function}

In adult liver detoxification genes are transcriptionally regulated in part by xenoreceptors PXR (pregnane X receptor), CAR (constitutive androstane receptor) and 
AhR (aryl-hydrocarbon receptor) [57-59]. CAR and PXR expression is regulated by HNF4 $\alpha 1$ and GR [60]. PXR mRNA was detectable in undifferentiated HuES-1 cells, and its expression increased slightly from D10 to D21 to reach $3 \%$ of PCHH expression levels (Table 1E). CAR mRNA expression peaked at D15 (as observed with $\mathrm{C} / \mathrm{EBP} \alpha$ and TTR), representing $25 \%$ of PCHH expression level. This mRNA was barely detectable in FL and was considered as another marker of hepatocyte maturation. AhR was expressed at a significant level during the differentiation process, in accordance with the expression of its target gene, CYP1A1.

GR mRNA expression increased during differentiation to reach a level close to that of PCHH (Table 1E). Since GR is a central transcription factor for many cellular processes, we decided to evaluate its functionality. At D21, ES-Hep culture medium was depleted of dexamethasone for $16 \mathrm{~h}$ and then re-supplemented with $5 \mu \mathrm{M}$ dexamethasone for $24 \mathrm{~h}$. The expression of a series of genes (supplementary Fig. 4) was analyzed before and after depletion, as well as $24 \mathrm{~h}$ after re-supplementation. The results provide clear evidence that this receptor is functional, as shown by the expected modulation of several target genes, TAT, CAR, PXR, CPS1, G6P and TTR. Interestingly, FOXA2 expression was not affected by dexamethasone, consistent with its expression reaching maximum levels at D10.

\section{Expression of miRNA-122}

miR-122 is liver specific and highly expressed at similar levels in human fetal liver (aged between 9 and 27 weeks) and adult liver [61]. In ES-Hep, its expression increased gradually during differentiation to reach a level close to $20 \%$ of that observed in PCHH (Table 1F).

\section{Differentiation of NPE Cells to Hepatocyte-like Cells}

We comparatively analyzed the expression of the same gene battery during adult NPE cell differentiation between D1 and D18 (Table 1). In contrast to hESC, these cells were not sensitive to OSM (not shown). Major differences between the differentiation processes of these two cell types were apparent. The transcription factors FOXA2, C/ $\mathrm{EBP} \alpha, \mathrm{HNF} 4 \alpha$ and HNF6 were expressed at much lower levels in NPE-Hep compared to ES-Hep. Similarly, AFP, TTR (target genes of HNF6), FII, CYP7A1, CPS1, PKL, CYP3A7, UGT1A1, GSTA3, PXR and CAR exhibited lower levels of expression in NPE-Hep. In contrast, other markers such as $\mathrm{C} / \mathrm{EBP} \beta, \mathrm{XBP} 1$, albumin, AAT, ApoH, FV, TO, TAT, G6P, GS, CYP1A1, CYP1A2, CYP2B6, CYP3A4, POR, SLC21A6, GSTP1, AhR, GR, SRC1 and PGC1 $\alpha$ were expressed at similar levels in both hES and NPE-derived hepatocyte-like cells.
Transduction of CAR in ES Cells

Previous investigations have shown that forced expression of transcription factor(s) can dramatically change cellular fates, inducing pluripotency, as in iPS cells [62, 63], promoting transdifferentiation in certain somatic cells [64, 65], or enhancing differentiation in carcinoma cells [66]. The xenosensor CAR regulates the expression of CYP $2 / 3$ and other xenobiotic conjugation and transporter genes after activation by exogenous compounds (such as phenobarbital or CITCO), or through its constitutive activity when transfected [59]. Since CAR is expressed at a low level in our ES-Hep, and as its expression is a marker of adult phenotype, we decided to study the impact of its lentivirusmediated expression in ES-Hep, using HepG2-C3 cells for comparison. Transduction experiments carried out at D15 or D20 gave similar results. The mRNA levels of phase I (CYP2B6, CYP2C9 and CYP3A4), phase II (UGT1A1) and phase III (SLC21A6) genes as well as biotransformation of midazolam (CYP3A4 substrate) to 1-OH-midazolam in ES-Hep were induced in a dose-dependent manner, reaching $2-20 \%$ of levels observed in PCHH (Fig. $4 a-b$, and supplementary Fig. 5). Clotrimazole, a potent deactivator of CAR [67], significantly repressed both the expression of these genes and midazolam activity, as expected [68]. However, analysis of cells several days after the induction of lentivirus-mediated expression of CAR revealed that this xenosensor is down regulated from $100 \%$ (level after forced expression at D20) to $20 \%$ at D27-31. As expected, all CAR-target genes were down regulated in parallel (Fig. 4c). These results show that forced expression of transcription factors in ES-Hep cells may enhance, at least transiently, the differentiation status of these cells. Interestingly, CAR overexpression did not induce these mRNAs in HepG2-C3 cells (except for CYP2B6).

\section{Discussion}

In this work we have: i) optimized a protocol of differentiation of hES cells towards the hepatocyte phenotype, ii) characterized the differentiation level of hepatocyte-like cells derived from hES versus those derived from adult liver NPE by comparing them to $\mathrm{PCHH}$, adult and fetal liver, and iii) evaluated the effect of forced expression of the xenoreceptor CAR in hES-derived hepatocyte-like cells on the expression of several markers of the hepatocyte detoxification function.

Numerous approaches have been developed to generate hepatocyte-like cells from hES cells [23-29]. Classical protocols used culture media with high glucose concentration $(25 \mathrm{mM})$, arguing that highly proliferating cells need more energy. However, a more physiologic glucose 


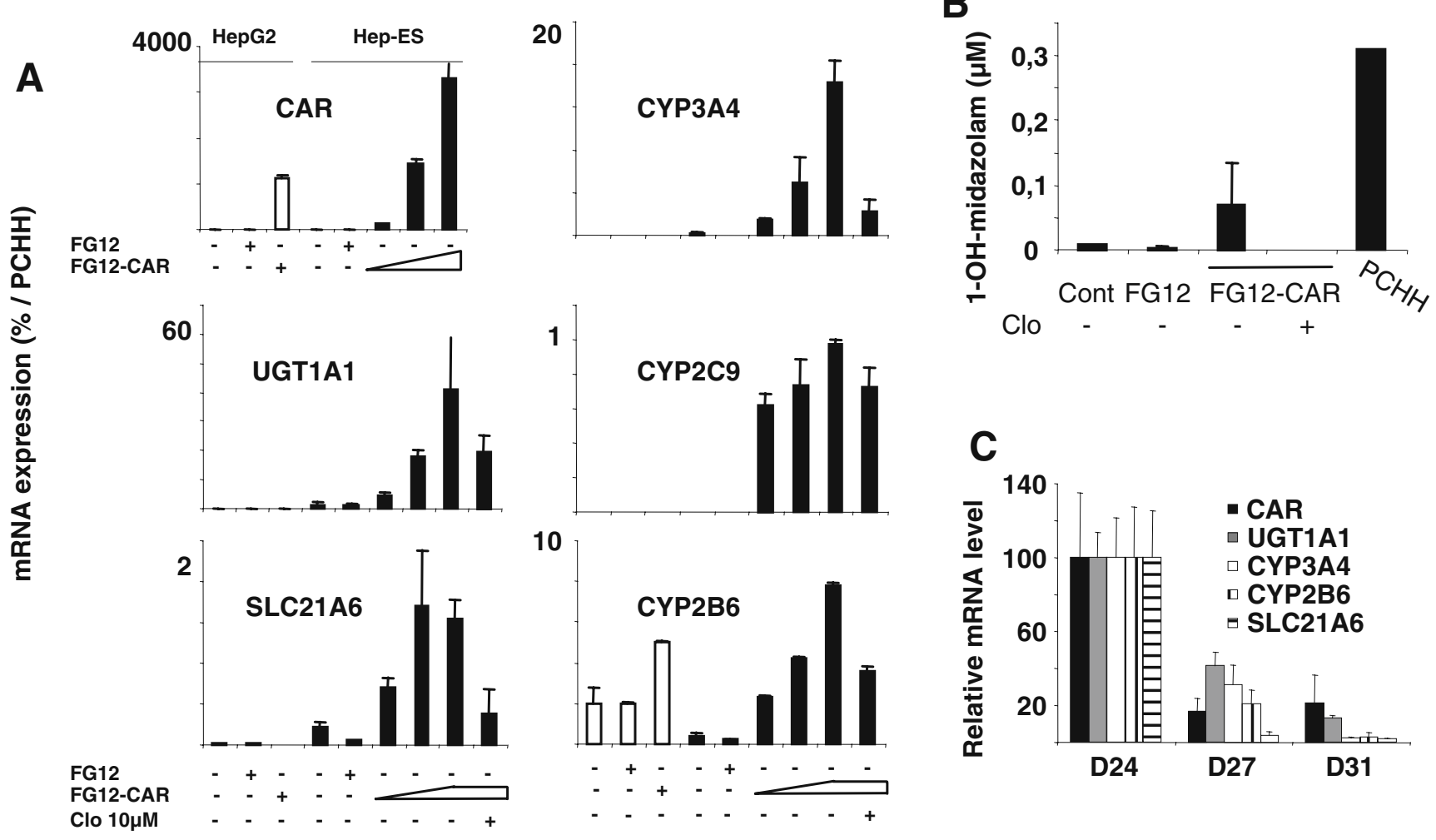

Fig. 4 Effect of CAR transduction. a Detoxication gene expression in HepG2-C3 and ES-Hep transduced with lentivirus harboring CAR (FG12-CAR) or control (FG12) plasmid at D15 and $48 \mathrm{~h}$ later treated

concentration $(5.5 \mathrm{mM})$ better promotes the in vitro development of mouse and human embryos [69, 70] and the formation of embryoid bodies [71]. Moreover, high glucose concentration enhances PI3-kinase activation and oxidative stress [72]. Our finding that DE markers reached higher levels in low glucose medium than in high glucose medium (Fig. 2) is consistent with these observations. Wnt3a signaling plays an important role in hESC selfrenewal and differentiation [73]. Since duration of signaling is critical (along with magnitude) [74], we explored the possibility of adapting the duration of Wnt3a treatment. We showed that a short exposure of cells to Wnt3a (between D1 and D3) was optimal for DE marker expression (Fig. 2). The differentiation protocol was further improved by adopting conditions used to differentiate adult liver NPE cells [31]. These included the use of $1 \%$ DMSO and $2 \%$ KO-SR during hepatic specification (supplementary Fig. 1), and plating of cells on type-I collagen at D10, followed by overlay of matrigel starting at D11. This substratum is apparently optimal for $\mathrm{PCHH}$ both in our hands and as published [44]. Admittedly, ALB expression is not the ideal hepatocyte marker as supported by our observations that primary human hepatocytes are heterogeneous in this respect (see Fig. 1d and supplementary Fig. 2B). However, in the absence of an alternative consensual hepatocyte for $24 \mathrm{H}$ with $1 \mu \mathrm{M}$ clotrimazole. b 1-OH-midazolam production (see supplementary Fig. 5). c Gene down-regulation after CAR transduction at D20

marker, this parameter was used to monitor cell differentiation. In spite of our efforts to increase yield, ES-Hep only represent approximately $40 \%$ of cells at the end of the differentiation protocol and are likely to be heterogeneous in terms of the extent of their differentiation. This may account for the modest level of expression of hepatic markers as compared with PCHH (Table 1). It is remarkable that among the 41 genes tested here, 29 exhibited a more or less sharp increase between D15 and D21 of differentiation. Hence, it may be argued that longer period of differentiation would result in better maturation. However, this was not the case (not shown). Apparently, the cell phenotype was not maintained in ES-Hep beyond D21, in our conditions. Whether this is related to the finding that the master regulators of hepatospecific genes such as FOXA2, $\mathrm{C} / \mathrm{EBP} \alpha$, and $\mathrm{HFN} 4 \alpha 1$ (Table 1) [47] reached maximum levels between D10 and D15 and decreased thereafter is currently unknown and will require further investigation. The observation that CAR expression rapidly declines after lentivirus transduction of cells between D24 and 31 (Fig. 4c) may be a consequence of this process.

The main objective of hES cell differentiation is to generate mature hepatocytes for biotherapy, basic research, pharmacology and toxicology. It is therefore important to select the most appropriate cellular controls and markers to 
evaluate the degree of differentiation of the generated cells. Some of the previous studies used controls that are not fully pertinent in this respect, including HepG2 cells which are certainly not "hepatocytes" [41], or undifferentiated ES cells [29]. In these cases, the high induction ratios of gene expression which were reported during differentiation should not be interpreted as a high level of differentiation, but merely reflect the low level of gene expression (if any) in the control cells (HepG2 or undifferentiated ES, Table 1). In addition, semi-quantitative PCR is frequently used with a high number of cycles $(>35)$, rendering questionable the biological significance of detected signals $[25,75,76]$. Moreover, comparative analysis reveals important differences between rodent and human development [21, 22], raising the question of whether studies on rodents can be extrapolated to humans [77]. For instance, the human embryo catabolizes amino acids for energy production whereas the rodent embryo does not. Some authors referred to the expression of genes that are not human adult markers, but fetal markers instead (CYP3A7) [29]. It is therefore important not to rely exclusively on rodent markers, and a list of human-specific development and adult markers should be documented. Finally, demonstrating that some CYP substrates for instance are metabolized by ESHep does not mean these cells are mature hepatocytes [75]. In this study, we therefore made a quantitative RT-PCR analysis of genes in ES-Hep versus fetal liver, adult liver and PCHH to estimate the developmental "age" of hepatocyte-like cells. Human adult hepatocyte markers used included $\mathrm{C} / \mathrm{EBP} \alpha$, CYP7A1, CYP1A2, CYP2B6, CYP3A4, UGT1A1 and CAR (Table 1) for which there is a good agreement with rodent data [50, 54-56, 78, 79]. However, other genes appear to be adult markers in rodents but not in humans. TO is switched on in rat liver shortly after birth [11], and is therefore currently used as a maturation marker in $\mathrm{mES}$ differentiation [25]. Micro-array data [56] (fetal liver 15-24 weeks) and our results on a FL sample (20-23 weeks) (Table 1) show that TO is expressed in human FL at midgestation. TAT mRNA is expressed in rat liver after birth [12], but is again detected earlier (mid-gestation) in human liver [14] (Table 1). CPS1 activity is detected in rodents in the perinatal period and increases over 4 weeks post-partum to reach the level detected in adults [15], while in humans CPS1 can be detected as early as week 5 of gestation [16], with consistent enzymatic activity [17]. The rat ortholog SLC21A5 has been shown to increase gradually during postnatal development [18], while SLC21A6 mRNA is expressed in human fetal liver, and therefore cannot be considered as an adult marker. Human fetal hepatocyte markers used in this work included AFP, CYP3A7 and GSTP1. CYP3A7 is specifically expressed in the human fetal liver and is gradually replaced by CYP3A4 in the periand post-natal period. Interestingly, the couple GSTP1-
GSTA3 behaves similarly, GSTP1 being the fetal counterpart. According to the results presented in Table 1 concerning the relative levels of expression of these various adult and fetal markers, we conclude that ES-Hep obtained in this study are representative of fetal hepatocytes at less than 20 weeks of gestation [21].

We previously reported that hepatocyte-like cells can be derived from NPE cells which are likely to contain adult liver progenitors [30]. It was therefore interesting to compare the level of differentiation reached in ES-Hep versus NPE-Hep (Table 1). In ES-Hep at D21, the levels of 14 genes were greater by at least one order of magnitude than in NPE-Hep at D18, including notably adult markers such as $\mathrm{C} / \mathrm{EBP} \alpha$, CYP7A1 and CAR. This would suggest that after a 3 week differentiation period, ES-Hep have reached a higher level of maturation than NPE-Hep. Indeed, when making a gene by gene comparison (excluding AFP), it appears that NPE-Hep at D18 exhibit a phenotype that is close to the phenotype displayed by ES-Hep between D5 and D10. However, this does not necessarily mean that ES- and NPE-derived hepatocyte-like cells pass through a common step during differentiation. On the other hand, levels of fetal markers AFP and CYP3A7 in NPE-Hep at D18 or before were much lower than in ES-Hep, suggesting that these cells are less "fetal". Recently, it has been suggested [80] that two populations of stem cells are present in the adult liver, HpSCs (AFP-/CYP3A7-) and hepatoblasts (AFP+/CYP3A7+) and that hepatoblasts derive from HpSCs. It is therefore possible that our NPE cells are more closely related to HpSCs than hepatoblasts. However, during NPE differentiation AFP and CYP3A7 expression both increase moderately, remaining much lower (3-4 orders of magnitude) than levels observed in FL and ES-Hep. This suggests that NPE-Hep have not yet reached the hepatoblast stage, although it can be noted that several other liver markers are expressed in these cells at a level close to that of FL and ES-Hep. We can thus conclude that during differentiation stem cells of different origins are likely to follow and rely upon different pathways of gene regulation and expression. Interestingly, it clearly appears that despite being considered as a liver specific marker, albumin is certainly not a hepatocyte maturation marker as it reaches in ES-Hep, NPE-Hep and FL levels close to or greater than those observed in $\mathrm{PCHH}$.

Detoxification is one of the major functions of adult hepatocytes. Generating hepatocyte-like cells from hES cells or other sources of stem cells represents therefore a major endeavor for investigating drug/xenobiotic metabolism, side effects and toxicity. Here we tested the impact of overexpressing the xenosensor CAR in ES-Hep. It is remarkable that several detoxification genes including CYP2B6, CYP2C9, CYP3A4, UGT1A1 and SLC21A6, as well as biotransformation of midazolam, a CYP3A4-specific substrate, were strongly induced in these conditions (Fig. 4 and supplementary 
Fig. 5). Interestingly, the use of clotrimazole as a CAR deactivator, fully confirmed the role of this xenosensor in these observations. This approach opens the way to future explorations using other xenosensors (PXR) or transcription factors. However, despite greater levels of CAR in transduced ES Hep compared to $\mathrm{PCHH}$, the levels of detoxification gene mRNAs reached only $2-20 \%$ of their levels in PCHH. This suggests that CAR is necessary but not sufficient in this respect. Indeed, Jover et al. [66] reported on a cooperation between $\mathrm{CAR}$ and $\mathrm{C} / \mathrm{EBP} \alpha$ on $\mathrm{CYP}$ gene expression. Co-transfection of xenosensors and other liver enriched transcription factors should be tested in future studies to optimize xenobiotic metabolism in stem cell-derived hepatocytes. Interestingly, similar transduction of HepG2-C3 cells by CAR had almost no impact on detoxification gene expression. Indeed, except for CYP2B6, not a single gene among CYP2C9, CYP3A4, SLC21A6 and UGT1A1 was induced significantly in HepG2-C3 cells, underscoring the importance of the cellular context in this respect, i.e. transcription factor cooperativity and epigenetic events.

\section{Conclusion}

In conclusion, we have adapted a robust protocol of differentiation of hES cells to hepatocyte-like cells. Our analysis of the expression of a panel of 41 genes and comparison with human fetal and adult liver, and primary hepatocytes suggests that our ES-Hep are representative of fetal hepatocytes of less than 20 weeks of gestation. ESHep apparently reach a better level of maturation as compared with adult NPE-Hep. Transduction of ES-Hep with CAR produced a massive increase of expression of genes involved in the detoxification function.

Acknowledgements HUES-1 cells were obtained from Dr Douglas Melton, Harvard University. This work was supported in part by grants from: Fondation de l'Avenir (ES and NPE cells), the European Community (Predictomics) and Sanofi-Aventis (NPE cells).

Disclosure of potential conflicts of interest To the best of our knowledge, there is no conflict of interest for any of the authors.

Open Access This article is distributed under the terms of the Creative Commons Attribution Noncommercial License which permits any noncommercial use, distribution, and reproduction in any medium, provided the original author(s) and source are credited.

\section{References}

1. Zaret, K. S. (2002). Regulatory phases of early liver development: paradigms of organogenesis. Nature Reviews Genetics, 3(7), 499512 .
2. Zorn, A. M., \& Wells, J. M. (2007). Molecular basis of vertebrate endoderm development. International Review of Cytology, 259, 49-111.

3. Gouon-Evans, V., Boussemart, L., Gadue, P., et al. (2006). BMP-4 is required for hepatic specification of mouse embryonic stem cell-derived definitive endoderm. Nature Biotechnology, 24(11), 1402-1411.

4. Calmont, A., Wandzioch, E., Tremblay, K. D., et al. (2006). An FGF response pathway that mediates hepatic gene induction in embryonic endoderm cells. Developmental Cell, 11(3), 339-348.

5. Zaret, K. S. (2001). Hepatocyte differentiation: from the endoderm and beyond. Current Opinion in Genetics \& Development, $11(5), 568-574$.

6. Matsumoto, K., Yoshitomi, H., Rossant, J., \& Zaret, K. S. (2001). Liver organogenesis promoted by endothelial cells prior to vascular function. Science, 294(5542), 559-563.

7. Zong, Y., Panikkar, A., Xu, J., et al. (2009). Notch signaling controls liver development by regulating biliary differentiation. Development, 136(10), 1727-1739.

8. Clotman, F., \& Lemaigre, F. P. (2006). Control of hepatic differentiation by activin/TGFbeta signaling. Cell Cycle, 5(2), $168-171$

9. Kamiya, A., Kinoshita, T., \& Miyajima, A. (2001). Oncostatin M and hepatocyte growth factor induce hepatic maturation via distinct signaling pathways. FEBS Letters, 492(1-2), 90-94.

10. Lazaro, C. A., Croager, E. J., Mitchell, C., et al. (2003). Establishment, characterization, and long-term maintenance of cultures of human fetal hepatocytes. Hepatology, 38(5), 10951106.

11. Kaltschmidt, C., Muller, M., Brem, G., \& Renkawitz, R. (1994). DNase I hypersensitive sites far upstream of the rat tryptophan oxygenase gene direct developmentally regulated transcription in livers of transgenic mice. Mechanisms of Development, 45(3), 203-210.

12. Greengard, O. (1969). Enzymic differentiation in mammalian liver injection of fetal rats with hormones causes the premature formation of liver enzymes. Science, 163(870), 891-895.

13. Greengard, O. (1977). Enzymic differentiation of human liver: comparison with the rat model. Pediatric Research, 11(5), 669676.

14. Andersson, S. M., Raiha, N. C., \& Ohisalo, J. J. (1980). Tyrosine aminotransferase activity in human fetal liver. Journal of Developmental Physiology, 2(1-2), 17-27.

15. Lamers, W. H., \& Mooren, P. G. (1980). Role of glucocorticosteroid hormones on the levels of rat liver carbamoylphosphate synthase (ammonia) and arginase activity during ontogenesis. Biology of the Neonate, 37(3-4), 113-137.

16. Moorman, A. F., Vermeulen, J. L., Charles, R., \& Lamers, W. H. (1989). Localization of ammonia-metabolizing enzymes in human liver: ontogenesis of heterogeneity. Hepatology, 9(3), 367-372.

17. Mukarram Ali Baig, M., Habibullah, C. M., Swamy, M., et al. (1992). Studies on urea cycle enzyme levels in the human fetal liver at different gestational ages. Pediatric Research, 31(2), 143145.

18. Guo, G. L., Johnson, D. R., \& Klaassen, C. D. (2002). Postnatal expression and induction by pregnenolone-16alpha-carbonitrile of the organic anion-transporting polypeptide 2 in rat liver. Drug Metabolism and Disposition, 30(3), 283-288.

19. Collardeau-Frachon, S., \& Scoazec, J. Y. (2008). Vascular development and differentiation during human liver organogenesis. Anatomical Record (Hoboken), 291(6), 614-627.

20. Yu, Y., Zhang, C., Zhou, G., et al. (2001). Gene expression profiling in human fetal liver and identification of tissue- and developmental-stage-specific genes through compiled expression profiles and efficient cloning of full-length cDNAs. Genome Research, 11(8), 1392-1403. 
21. Brizard, J. P., Ramos, J., Robert, A., et al. (2009). Identification of proteomic changes during human liver development by 2D-DIGE and mass spectrometry. Journal of Hepatology, 51(1), 114-126.

22. Nagata, T., Takahashi, Y., Ishii, Y., et al. (2003). Profiling of genes differentially expressed between fetal liver and postnatal liver using high-density oligonucleotide DNA array. International Journal of Molecular Medicine, 11(6), 713-721.

23. Carpenter, M. K., Rosler, E., \& Rao, M. S. (2003). Characterization and differentiation of human embryonic stem cells. Cloning and Stem Cells, 5(1), 79-88.

24. Lavon, N., Yanuka, O., \& Benvenisty, N. (2004). Differentiation and isolation of hepatic-like cells from human embryonic stem cells. Differentiation, 72(5), 230-238.

25. Cai, J., Zhao, Y., Liu, Y., et al. (2007). Directed differentiation of human embryonic stem cells into functional hepatic cells. Hepatology, 45(5), 1229-1239.

26. Basma, H., Soto-Gutierrez, A., Yannam, G. R., et al. (2009). Differentiation and transplantation of human embryonic stem cellderived hepatocytes. Gastroenterology, 136(3), 990-999.

27. Brolen G., Sivertsson L., Bjorquist P., et al., (2009). Hepatocytelike cells derived from human embryonic stem cells specifically via definitive endoderm and a progenitor stage. Journal of Biotechnology.

28. Si-Tayeb, K., Noto, F. K., Nagaoka, M., et al. (2010). Highly efficient generation of human hepatocyte-like cells from induced pluripotent stem cells. Hepatology, 51(1), 297-305.

29. Touboul, T., Hannan, N. R., Corbineau, S., et al. (2010). Generation of functional hepatocytes from human embryonic stem cells under chemically defined conditions that recapitulate liver development. Hepatology, 51(5), 1754-1765.

30. Duret, C., Gerbal-Chaloin, S., Ramos, J., et al. (2007). Isolation, characterization, and differentiation to hepatocyte-like cells of nonparenchymal epithelial cells from adult human liver. Stem Cells, 25(7), 1779-1790.

31. Gerbal-Chaloin, S., Duret, C., Raulet, E., et al. (2010). Isolation and culture of adult human liver progenitor cells: in vitro differentiation to hepatocyte-like cells. Methods in Molecular Biology, 640, 247-260.

32. Isom, H. C., Secott, T., Georgoff, I., Woodworth, C., \& Mummaw, J. (1985). Maintenance of differentiated rat hepatocytes in primary culture. Proceedings of the National Academy of Sciences of the United States of America, 82(10), 3252-3256.

33. Raymond, C. K., Roberts, B. S., Garrett-Engele, P., Lim, L. P., \& Johnson, J. M. (2005). Simple, quantitative primer-extension PCR assay for direct monitoring of microRNAs and short-interfering RNAs. RNA, 11(11), 1737-1744.

34. Qin, X. F., An, D. S., Chen, I. S., \& Baltimore, D. (2003). Inhibiting HIV-1 infection in human T cells by lentiviral-mediated delivery of small interfering RNA against CCR5. Proceedings of the National Academy of Sciences of the United States of America, 100(1), 183-188.

35. Moreau, A., Vilarem, M. J., Maurel, P., \& Pascussi, J. M. (2008). Xenoreceptors CAR and PXR activation and consequences on lipid metabolism, glucose homeostasis, and inflammatory response. Molecular Pharmaceutics, 5(1), 35-41.

36. Pascussi J. M., Robert A., Moreau A., et al., (2007). Differential regulation of Constitutive Androstane Receptor expression by Hepatocyte Nuclear Factor4alpha isoforms. Hepatology. (in press).

37. D'Amour, K. A., Agulnick, A. D., Eliazer, S., Kelly, O. G., Kroon, E., \& Baetge, E. E. (2005). Efficient differentiation of human embryonic stem cells to definitive endoderm. Nature Biotechnology, 23(12), 1534-1541.

38. McLean, A. B., D’Amour, K. A., Jones, K. L., et al. (2007). Activin a efficiently specifies definitive endoderm from human embryonic stem cells only when phosphatidylinositol 3-kinase signaling is suppressed. Stem Cells, 25(1), 29-38.
39. Gadue, P., Huber, T. L., Paddison, P. J., \& Keller, G. M. (2006). Wnt and TGF-beta signaling are required for the induction of an in vitro model of primitive streak formation using embryonic stem cells. Proceedings of the National Academy of Sciences of the United States of America, 103(45), 16806-16811.

40. Sullivan, G. J., Hay, D. C., Park, I. H., et al. (2010). Generation of functional human hepatic endoderm from human induced pluripotent stem cells. Hepatology, 51(1), 329-335.

41. Hay, D. C., Zhao, D., Fletcher, J., et al. (2008). Efficient differentiation of hepatocytes from human embryonic stem cells exhibiting markers recapitulating liver development in vivo. Stem Cells, 26(4), 894-902.

42. Jung, J., Zheng, M., Goldfarb, M., \& Zaret, K. S. (1999). Initiation of mammalian liver development from endoderm by fibroblast growth factors. Science, 284(5422), 1998-2003.

43. Iwatani, M., Ikegami, K., Kremenska, Y., et al. (2006). Dimethyl sulfoxide has an impact on epigenetic profile in mouse embryoid body. Stem Cells, 24(11), 2549-2556.

44. McClelland, R., Wauthier, E., Uronis, J., \& Reid, L. (2008). Gradients in the liver's extracellular matrix chemistry from periportal to pericentral zones: influence on human hepatic progenitors. Tissue Engineering Part A, 14(1), 59-70.

45. Schwartz, R. E., Reyes, M., Koodie, L., et al. (2002). Multipotent adult progenitor cells from bone marrow differentiate into functional hepatocyte-like cells. Journal of Clinical Investigation, 109(10), 1291-1302.

46. Kamiya, A., Kojima, N., Kinoshita, T., Sakai, Y., \& Miyaijma, A. (2002). Maturation of fetal hepatocytes in vitro by extracellular matrices and oncostatin $\mathrm{M}$ : induction of tryptophan oxygenase. Hepatology, 35(6), 1351-1359.

47. Costa, R. H., Kalinichenko, V. V., Holterman, A. X., \& Wang, X. (2003). Transcription factors in liver development, differentiation, and regeneration. Hepatology, 38(6), 1331-1347.

48. Briancon, N., Bailly, A., Clotman, F., Jacquemin, P., Lemaigre, F. P., \& Weiss, M. C. (2004). Expression of the alpha7 isoform of hepatocyte nuclear factor (HNF) 4 is activated by HNF6/OC-2 and HNF1 and repressed by HNF4alpha1 in the liver. The Journal of Biological Chemistry, 279(32), 33398-33408.

49. Klover, P. J., \& Mooney, R. A. (2004). Hepatocytes: critical for glucose homeostasis. The International Journal of Biochemistry \& Cell Biology, 36(5), 753-758.

50. Massimi, M., Lear, S. R., Huling, S. L., Jones, A. L., \& Erickson, S. K. (1998). Cholesterol 7alpha-hydroxylase (CYP7A): patterns of messenger RNA expression during rat liver development. Hepatology, 28(4), 1064-1072.

51. Postic, C., Dentin, R., \& Girard, J. (2004). Role of the liver in the control of carbohydrate and lipid homeostasis. Diabetes Metab., 30(5), 398-408.

52. Lewis, D. S., Oren, S., Wang, X., et al. (2000). Developmental changes in cholesterol 7alpha- and 27-hydroxylases in the piglet. Journal of Animal Science, 78(4), 943-951.

53. Gonzalez, F. J. (1992). Human cytochromes P450: problems and prospects. Trends in Pharmacological Sciences, 13(9), 346352.

54. Bieche, I., Narjoz, C., Asselah, T., et al. (2007). Reverse transcriptase-PCR quantification of mRNA levels from cytochrome (CYP)1, CYP2 and CYP3 families in 22 different human tissues. Pharmacogenetics and Genomics, 17(9), 731-742.

55. Strassburg, C. P., Strassburg, A., Kneip, S., et al. (2002). Developmental aspects of human hepatic drug glucuronidation in young children and adults. Gut, 50(2), 259-265.

56. Le Carrour, T., Assou, S., Tondeur, S., et al. (2010). Amazonia!: An online resource to google and visualize public human whole genome expression data. The Open Bioinformatics Journal, 4, 5-10.

57. Hankinson, O. (1995). The aryl hydrocarbon receptor complex. Annual Review of Pharmacology and Toxicology, 35, 307-340. 
58. Kliewer, S. A., Moore, J. T., Wade, L., et al. (1998). An orphan nuclear receptor activated by pregnanes defines a novel steroid signaling pathway. Cell, 92(1), 73-82.

59. Honkakoski, P., Zelko, I., Sueyoshi, T., \& Negishi, M. (1998). The nuclear orphan receptor CAR-retinoid X receptor heterodimer activates the phenobarbital-responsive enhancer module of the CYP2B gene. Molecular and Cellular Biology, 18(10), 56525658.

60. Pascussi, J. M., Gerbal-Chaloin, S., Duret, C., Daujat-Chavanieu, M., Vilarem, M. J., \& Maurel, P. (2008). The tangle of nuclear receptors that controls xenobiotic metabolism and transport: crosstalk and consequences. Annual Review of Pharmacology and Toxicology, 48, 1-32.

61. Tzur, G., Israel, A., Levy, A., et al. (2009). Comprehensive gene and microRNA expression profiling reveals a role for microRNAs in human liver development. PLoS ONE, 4(10), e7511.

62. Takahashi, K., Okita, K., Nakagawa, M., \& Yamanaka, S. (2007). Induction of pluripotent stem cells from fibroblast cultures. Nature Protocols, 2(12), 3081-3089.

63. Yu, J., Vodyanik, M. A., Smuga-Otto, K., et al. (2007). Induced pluripotent stem cell lines derived from human somatic cells. Science, 318(5858), 1917-1920.

64. Ieda, M., Fu, J. D., Delgado-Olguin, P., et al. (2010). Direct reprogramming of fibroblasts into functional cardiomyocytes by defined factors. Cell, 142(3), 375-386.

65. Vierbuchen, T., Ostermeier, A., Pang, Z. P., Kokubu, Y., Sudhof, T. C., \& Wernig, M. (2010). Direct conversion of fibroblasts to functional neurons by defined factors. Nature, 463(7284), 10351041.

66. Pascual, M., Gomez-Lechon, M. J., Castell, J. V., \& Jover, R. (2008). ATF5 is a highly abundant liver-enriched transcription factor that cooperates with constitutive androstane receptor in the transactivation of CYP2B6: implications in hepatic stress responses. Drug Metabolism and Disposition, 36(6), 1063-1072.

67. Moore, L. B., Parks, D. J., Jones, S. A., et al. (2000). Orphan nuclear receptors constitutive androstane receptor and pregnane $\mathrm{X}$ receptor share xenobiotic and steroid ligands. The Journal of Biological Chemistry, 275(20), 15122-15127.

68. Zhang, W., Ramamoorthy, Y., Kilicarslan, T., Nolte, H., Tyndale, R. F., \& Sellers, E. M. (2002). Inhibition of cytochromes P450 by antifungal imidazole derivatives. Drug Metabolism and Disposition, 30(3), 314-318.

69. Conaghan, J., Handyside, A. H., Winston, R. M., \& Leese, H. J. (1993). Effects of pyruvate and glucose on the development of human preimplantation embryos in vitro. Journal of Reproduction and Fertility, 99(1), 87-95.

70. Quinn, P., Moinipanah, R., Steinberg, J. M., \& Weathersbee, P. S. (1995). Successful human in vitro fertilization using a modified human tubal fluid medium lacking glucose and phosphate ions. Fertility and Sterility, 63(4), 922-924.

71. Khoo, M. L., McQuade, L. R., Smith, M. S., Lees, J. G., Sidhu, K. S., \& Tuch, B. E. (2005). Growth and differentiation of embryoid bodies derived from human embryonic stem cells: effect of glucose and basic fibroblast growth factor. Biology of Reproduction, 73(6), 1147-1156.

72. Kim, Y. H., Heo, J. S., \& Han, H. J. (2006). High glucose increase cell cycle regulatory proteins level of mouse embryonic stem cells via PI3-K/Akt and MAPKs signal pathways. Journal of Cellular Physiology, 209(1), 94-102.

73. Angers, S., \& Moon, R. T. (2009). Proximal events in Wnt signal transduction. Nature Reviews Molecular Cell Biology, 10(7), 468477.

74. Hansson, M., Olesen, D. R., Peterslund, J. M., et al. (2009). A late requirement for Wnt and $\mathrm{FGF}$ signaling during activin-induced formation of foregut endoderm from mouse embryonic stem cells. Developmental Biology, 330(2), 286-304.

75. Duan, Y., Ma, X., Zou, W., et al. (2010). Differentiation and characterization of metabolically functioning hepatocytes from human embryonic stem cells. Stem Cells, 28(4), 674686.

76. Zhao, D., Chen, S., Cai, J., et al. (2009). Derivation and characterization of hepatic progenitor cells from human embryonic stem cells. PLoS ONE, 4(7), e6468.

77. Dingemanse, M. A., \& Lamers, W. H. (1994). Expression patterns of ammonia-metabolizing enzymes in the liver, mesonephros, and gut of human embryos and their possible implications. The Anatomical Record, 238(4), 480-490.

78. Croniger, C., Leahy, P., Reshef, L., \& Hanson, R. W. (1998). C/ EBP and the control of phosphoenolpyruvate carboxykinase gene transcription in the liver. The Journal of Biological Chemistry, 273 (48), 31629-31632.

79. Timchenko, N. A., Harris, T. E., Wilde, M., et al. (1997). CCAAT/ enhancer binding protein alpha regulates p21 protein and hepatocyte proliferation in newborn mice. Molecular and Cellular Biology, 17(12), 7353-7361.

80. Zhang, L., Theise, N., Chua, M., \& Reid, L. M. (2008). The stem cell niche of human livers: symmetry between development and regeneration. Hepatology, 48(5), 1598-1607. 